\section{Reflections on the Challenge of our Age}

\author{
PAUL LAMPLE
}

\section{Abstract}

The disintegration of the old world order is increasingly evident in the inability of human beings to resolve their differences, as manifested in intractable disputes about knowledge, politics, morals, and economics. In the face of such challenges, the Bahá'í Faith seeks to unite humanity in the search for truth and the building of a just and peaceful world. The purpose of this paper is to explore how Bahá'ís expect to achieve these aims through the conscious and active transformation of the moral order - not by force or coercion but by example, persuasion, consensus, and cooperation.

\section{Résumé}

La désintégration de l'ancien ordre mondial se manifeste de plus en plus dans l'incapacité des êtres humains à résoudre leurs différends, comme le montrent les litiges persistants au sujet de la connaissance, de la politique, de la morale et de l'économie. Face à de tels défis, la foi bahá'íe cherche à unir l'humanité dans la recherche de la vérité et la construction d'un monde juste et pacifique. Le présent article vise à explorer comment les bahá'ís comptent y parvenir par une transformation consciente et active de l'ordre moral, non pas par la force et la contrainte, mais par l'exemple, la persuasion, le consensus et la coopération.

\section{Resumen}

La desintegración del viejo orden mundial es cada vez más evidente en la incapacidad de los seres humanos en poder resolver sus diferencias, que se manifiesta en disputas intratables sobre el conocimiento, la política, la moral y la economía. Frente a tales desafíos, la Fe Bahá'í busca unir a la humanidad en la búsqueda de la verdad y la construcción de un mundo justo y pacífico. El propósito de este ensayo es explorar como los Bahá'ís esperan lograr estos objetivos por medio de una transformación consciente y activa del orden moral, no por la fuerza o la coerción, sino por el ejemplo, la persuasión, el consenso y la cooperación.

\section{INTRODUCTION}

In 1925, a visitor to Palestine and the Middle East stopped for a time in Haifa and had a meeting with Shoghi Effendi. In a book recording her travels, she wrote of her response to that encounter:

They are a lovable and fascinating people, the Bahais: idealists who have dreamed a dream of peace that passes all understanding, who seek to bring relief to restless unhappy human hearts, who, by cooperation, would replace competition, and blend all races, religions, nations and classes into one harmonious whole. A beautiful dream, too good, it is feared, to come true in our present state of imperfection and atavistic crudity, but a dream that it is pleasant to come into contact with, as I did for a couple of hours, on a blazing April afternoon. (Mills, qtd. in Redman 100) 
This, of course, is not the only account of the Bahá'í Faith that sets it aside as a beautiful but unrealistic aspiration for humanity and sees Bahá'ís as having noble ideals but being unable to actually do anything to achieve them in a practical way. The challenge facing humanity is not simply a matter of stating how things ought to be, but of determining how that necessary transformation is to occur. Thus, the pressing question that arises is: How does such a small band of so-called idealists expect to be able to make their dream a reality?

As this astute observer noted, the problem is not that Bahá'í ideals are unworthy of attainment; rather, it is that the present state of human action is flawed and unable to bring such ideals into reality. The profound transformation required to achieve these high aims requires a process of change in thought and action that begins with that small band of "idealists" and increasingly embraces ever-larger numbers. The change encompasses not only what people do, but also who they are- the character of individuals and of culture. It is, fundamentally, a change in moral conception and practice, by individuals and by society as a whole.

Almost from the beginning of human existence, human beings asked themselves questions such as: What am I supposed to do? What ought human beings do? What kind of actions are right and what kind are wrong? What constitutes a good life and a good society? What do I owe to others? What is the nature of sound relationships among human beings and what form ought they take? The range of views in answer to such questions is wide. At one extreme, some view morality as the enactment of the immutable decrees of God as understood by human interpreters relying on a literal-or even ideological-perspective. At the other, some view moral language as expressing no more than preferences that vary from person to person and which amount to nothing more than statements about how one desires others to behave. Yet, even from the time of hunter-gatherer groups, the way people answered such questions had a profound impact, sometimes even determining whether a particular group flourished or ceased to exist.

The problem is particularly evident today when, as a result of the acceleration of the process of the disintegration of the old world order, people are increasing divided into different groups according to identity and moral purpose-different configurations of "us and them"-resulting in intractable differences with others. Increasingly, there is no shared conception of reality to resolve the differences among these groups. The outcome is a seemingly endless contest for power that results in a circle of high conflict and contention in discourse, social interaction, and political affairs. ${ }^{1}$ It is as if the picture

1 For an in-depth treatment of this subject, see Joshua Greene, Moral Tribes: Emotion, Reason, and the Gap Between Us and Them; Jonathan Haidt. The Righteous Mind: Why Good People are Divided by Politics and Religion; Michael Karlberg, 
of humanity has become a shattered mosaic, with no hope of finding a way to put the pieces back together in the form of just social relationships. Overcoming such seemingly intractable differences is the most pressing challenge of our age. The purpose of this paper is to explore the Bahá'í perspective on the nature of how the world ought to be and how to bring about the necessary change in society in accordance with the "standard of true morality" provided by the Bahá'í teachings ('Abdu'l-Bahá, Promulgation 66). The thoughts presented here are merely my personal perspective on this profound and weighty topic.

It is, of course, possible to simply examine in isolation Bahá'u'lláh's moral teachings. And it is possible to separately examine how the Bahá'í community is unfolding in its efforts to unite humanity. The purpose of this article, however, it to call to mind that these two things are inseparable — both as means and ends. "The purpose of justice is the appearance of unity among men," Bahá'u'lláh states. The unbreakable association between teaching and the moral order is explicated by Shoghi Effendi in The Advent of Divine Justice, written as Bahá'ís initiated their systematic execution of the Divine Plan. To understand the true nature of the work of the Bahá'í community, especially at this important moment of transition into a new series

Beyond the Culture of Contest; and Amanda Ripley, High Conflict: Why We Get Trapped and How We Get Out. of Plans ${ }^{2}$ and as the forces of disintegration grow in intensity, it is essential to appreciate the ongoing promulgation of divine justice.

\section{A Brief Overview of Moral Thought}

How has humanity sought answers to questions of morality and moral order? It is impossible, of course, in this limited space to adequately survey the range and depth of thinking on the question of morality across human history. Yet, it is useful to get a sense of how humanity has attempted to address such questions over time to better understand the context and intent of Bahá'u'lláh's teachings pertaining to morality, which are properly understood as part of the unfolding story of human history, and which provide the means by which human individual and social development will attain their maturity.

Tens of thousands - or perhaps even over a hundred thousand-years ago, religion emerged among groups of people to inform human identity and behavior. In various forms, and at various times and places, religion fostered the social cohesion that helped humanity evolve to ever higher levels of social complexity and order. It created bonds that allowed people to see themselves as one and, through its teachings, it conveyed a narrative

2 Global plans for the expansion and consolidation of the Bahá'í Faith. The first plans were initiated by Shoghi Effendi and they now unfold under the direction of the Universal House of Justice. 
concerning the nature of reality and the position and purpose of the human being within that reality. It provided a description of what is right and what is good, and how human beings should act, including how to act toward other human beings within and outside the religious community. In this manner, individuals were bound together in a shared pattern of life, a tradition, and a culture in which succeeding generations were raised and socialized.

The challenge for the moral guidance provided by religion is that, over time, human ideas begin to infiltrate the original teachings until they eventually overtake them. What was initially a center of unity and wellbeing can then become a vehicle for division and contention. Religion can even be reduced to an ideology, when certain beliefs or religious propositions are held to be the standard by which other human beings are judged and even persecuted as infidels, rather than maintaining a focus on improving morals and the common good.

Another contribution to moral thought, dating over thousands of years, is philosophy. The range of philosophical perspectives varies across cultures. Generally, philosophy uses reasoned argument to try to discern the nature of reality and the responsibilities of human beings across the range of the relationships they experience. Among the most prominent areas in moral philosophy, particularly in western or cosmopolitan thought, are utilitarianism, or consequentialism, which is concerned with ultimate outcomes - such as the greatest happiness for the greatest number; deontology which is concerned with the nature of moral rules or obligations that determine what is right or wrong; and virtue ethics, which emphasizes virtue or character expressed, through wisdom, in pursuit of the good life in a particular cultural context. Through these and other approaches, philosophy has sought to provide a moral foundation for political order, social progress, or economic systems.

Philosophy, however, has also given rise to schools of thought that challenge or displace the concept of morality. Emotivism, for example, suggests that ethical and value judgments are mere expressions of feelings, while nihilism rejects moral principles in the belief that life is meaningless. The rise of reason sought to contain - if not root out-religion, especially that form of religion that drifted far from its original teachings, thus contributing to severing humanity's allegiance to religion and its effects on the moral order (Hare). Philosophy ranges across a spectrum of thought that gives rise to various forms of ideology, in which particular ideas are held as the highest value to which human action must conform (W. Hatcher 1-4, World Order 42). This can take such forms as individualism, which stresses the importance of the individual, libertarianism, where freedom is the highest value that sets the standard for moral considerations, or the evolutionary struggle for existence in the form of social Darwinism or eugenics. One characteristic of 
philosophy is that discussion has no basis for final resolution (Heil 199200; 'Abdu'l-Bahá, Promulgation 21); thus, while philosophy over millennia has shed light on a range of issues pertaining to morality and the moral order, such investigations too often tend to be circular, with different arguments prevailing at different periods, rather than finding resolution and consensus on the basis of which moral progress can be consistently pursued.

Finally, in recent decades, various sciences have contributed significantly to moral thought, yielding a wide range of insights. For example, drawing from fields such as neuroscience, evolutionary biology, and cultural anthropology, moral psychology has sought to understand how the mind creates moral understanding and action. From this perspective, some see religion purely as a social phenomenon and understand it as a force for creating social cooperation that allowed some societies to overcome forces of self-interest to succeed in out-competing others in an evolutionary social contest. Virtues are simply evolutionary behaviors that contribute to cooperation, while vice is any developed behavior contributing to types of competition that undermine the viability of a particular form of social order (Lample). As another example, analysis of brain functioning in relation to moral reasoning and action reveals the automatic response of the brain's lower function, and a higher brain function that seems to be used after the initial response to morally justify the choices made; so-called "moral" actions are then considered to be the responses ingrained by evolution and by personal experience, for which the rational mind provides justification after the fact. Some experiments have demonstrated how prejudice is ingrained at a deep and habitual level of response that operates before conscious governance of behavior is invoked. Other experiments have even indicated that certain decisions - moving a leg, for instance - are witnessed in bodily movement even before signals in brain activity, prompting some to doubt the existence of free will.

Religion, philosophy, and psychology all offer certain insights into the relationship between morality and identity. Yet, the current moral order is profoundly disordered. Rather than a standard to which an individual or group seeks to conform, morality becomes something that bends to conform to human desires or to the will of those wielding power. As various factions of humanity pursue their own aims at the expense of others, morality is distorted to rationalize and justify those actions, and large portions of humanity are reduced to mere objects that others manipulate.

The challenge is to raise a new moral order which can encompass all humanity and is suited to the age of the maturity of the human race - the expression of the oneness of humanity in the reordering of life on the planet. "The morals of humanity must undergo change," 'Abdu'l-Bahá affirms. "Just as the thoughts and hypotheses of past ages are fruitless today, likewise 
dogmas and codes of human invention are obsolete and barren of product" (Promulgation 144).

Perhaps, as a starting point, the most useful conception of morality that can be drawn from these diverse perspectives concerns the nature of the relationships that place the human being in proper context with others and explains what is due to each - that is, what we owe to one another- thereby bringing about the empirical results of human flourishing - what is good, what is right, what is just-resulting in peace, unity, prosperity, a meaningful life, and the common good in the form of an ever-advancing civilization (see W. Hatcher, Scanlon, Wallace). Bahá'ís must seek to understand what Bahá'u'lláh has explained about such matters, learn how to translate this understanding into action, and share this perspective with others if the high ideals toward which they aim are to be achieved.

\section{BAHÁ'U'LLÁH AND THE STANDARD of True Morality}

An effort to understand Bahá'u'lláh's approach to morality and the moral life begins with some essential ideas drawn from His vast Revelation.

According to Bahá'u'lláh, every human being is endowed with a soul. This means that every person inherently possesses the power of the mind and consciousness. Every person is endowed with a heart - a capacity for love and other powerful and uplifting emotions. Every person is endowed with a will - with volition and agency - the capacity to act on the basis of free choice in the world. Every person has the capacity to manifest all spiritual virtues-human expressions of the names and attributes of God. Freedom of conscience has been bestowed upon everyone. A human being, then, is more than a body, more than a mere animal seeking to satisfy its instinctive desires. The purpose of life in this world is to give full expression to these powers of the soul. Every person appears on the earth to express the potentialities of this endowment through the creative act of developing and utilizing these powers to live a meaningful, just, virtuous, and fulfilling life.

The endowment received by every person is identical in nature. This identical nature creates an equality of condition among human beings that must be respected. "Each sees in the other the Beauty of God reflected in the soul, and finding this point of similarity, they are attracted to one another in love," 'Abdu'l-Bahá states (Paris Talks 180). The reality of the human being, the soul, is not differentiated by those things on whose basis human beings tend to judge and divide themselves from one another, such as gender, race, or nationality; the soul, in its essence, is free of such characteristics. This common endowment is the basis for human honor-the rights and dignity owed to every person. Yet, this endowment is not identical in measure. "The portion of some," Bahá'u'lláh states, "might lie in the palm of a man's hand, the portion of others might fill a cup, and of others 
even a gallon-measure." This natural difference is an expression of diversity, but offers no justification for discrimination. He states: "Let none, therefore, consider the largeness or smallness of the receptacle." Rather, "The whole duty of man in this Day is to attain that share of the flood of grace which God poureth forth for him" (Gleanings 5:4). The extent to which each person gives expression to these latent potentialities for their proper purpose is that which gives distinction to a human life - not those ephemeral measures assigned by human societies of fame, wealth, class, or calling. "How excellent, how honorable is man if he arises to fulfil his responsibilities;" "Abdu'l-Bahá explains, "how wretched and contemptible, if he shuts his eyes to the welfare of society and wastes his precious life in pursuing his own selfish interests and personal advantages" (Secret 4 ).

Bahá'u'lláh further indicates that human beings are social beings. A soul born into this world is immediately a part of a social order. The community, the society, is both the social environment that shapes and educates a human being, empowering that soul to give expression to its latent potentialities to live a good and meaningful life, and is, in its own right, an actor, a protagonist, manifesting itself, throughout history, in ever-larger, ever more complex forms of social organization. As a participant in the social order, human beings, under the guidance of the Manifestation of God, create and are created by social relationships. The nature of these social relationships, the framework of what one human being owes to others, is born out of the shared endowment of the soul. One cannot justifiably claim for oneself the right to give full expression to one's own latent divine endowment without implicitly granting that right to all others to give expression to their own. Thus, the golden rule, to treat others as one wishes to be treated, is a moral exhortation found in every religion. Equality of condition requires justice, where each person receives what is due, which is the right to express these inherent capacities. In this way, every human being may be considered the trust of society. It is immoral and unjust that, in the pursuit of selfish benefit, an individual or a group deprive another individual or group of the possibilities of expressing these inherent human potentialities; any configuration of the social order that creates these unjust conditions would constitute a form of oppression. This is the "struggle for existence" decried by both Bahá'u'lláh and 'Abdu'l-Bahá (qtd. in Messages:1986-2001 215.2, Selections 227:10).

For millennia, the social order has evolved-from clans, to tribes, to city states, to nations, and now, to the threshold of a unified world (Shoghi Effendi, Promised Day 192-93). At each stage of this development, religion has been a force for uniting humanity at ever-wider levels of social organization - a conclusion argued by historians and even by evolutionary biologists. This story of the unfoldment of civilization and the progress of the human race is captured by 
Bahá'u'lláh's description of progressive revelation. In every age, the "object of every Revelation" He states, is "to effect a transformation in the whole character of mankind, a transformation that shall manifest itself both outwardly and inwardly, that shall affect both its inner life and external conditions" (Kitab-i-Íqán 240).

Thus, the description of what the inner and outer life ought to be in this age is set forth in Bahá'u'lláh's writings (Tablets 130). The determination of what that inner life ought to be is based on the true nature of the human being, as well as on the capacity for cultivating and expressing that nature to the extent possible based on the current stage of human social evolution. The determination of what that outer life ought to be pertains to overcoming the challenges that inhibit the advance of the most recent stage in humanity's organic social development. Such descriptions and exhortations in the Bahá'í Writings are not arbitrary — based on a kind of divine whim; Bahá'u'lláh does not ask for blind obedience or mere submission to divine command. Faith, for Bahá'ís, is conscious knowledge and action (Universal House of Justice, 22 October 1996). The Bahá'í teachings are based on the reality of human nature and social wellbeing, and their effective implementation is intended to create an empirically demonstrable improvement in the human condition. "The Laws of God are not imposition of will, or of power, or pleasure," 'Abdu'l-Bahá affirms, "but the resolutions of truth, reason and justice" (Paris Talks 154).
At each stage of social evolution up to this point, the social order created by human beings was founded on some conception of "us and them." While outwardly this divided human beings, it nevertheless served as an effective instrument for uniting them, gradually forging an ever-growing circle of those considered to share a common identity-an "us." Each dispensation expanded the circle of unity, the concept of "us," assisting humanity to achieve the next, larger, and more complex, stage of its social development. Yet, at the same time, this process of "othering" allowed for two standards of morality and justified differential treatment of those who were not considered the same as oneself or one's community-even to such extremes as oppression, slavery, or genocide. By ushering in the age of the maturity of the human race, Bahá'u'lláh has brought an end to any justification for otherness and has now made it possible to create a society that gives expression to the oneness of humanity. The essential reality of human nature - its oneness - is now to find expression in the social order ('Abdu'l-Bahá, Paris Talks 53). What 'Abdu'l-Bahá described as the "standard of true morality" (Promulgation 66), the obligations that rest upon every human being and every human society including the institutions that make social order possible, apply to all without exception. The question, now, is how to so order human affairs that the right of every person to manifest their divine endowment is not compromised but, rather, is cultivated in a just 
society that safeguards the common good.

The twofold purpose of the Manifestation of God to transform the inner and outer life of humanity finds its complement in the twofold moral purpose of every individual soul to transform the self and to contribute to transforming society. In the first, a person gives expression to the inherent powers of the soul in an act of moral artistry that weaves the rich tapestry of a righteous, good, worthy, and meaningful life. In the second, a person acts as a citizen of the world, making choices in association with others that contribute, as many drops join to make a mighty river, to the formation of united, just, prosperous, and peaceful social spaces, leading ultimately to the attainment of the common good and an ever-advancing civilization.

It is through His teachings that Bahá'u'lláh provides the insight and guidance necessary for such a profound change in human affairs. His teachings redefine human relationships for a global civilization in the age of maturity of the human race. This includes the relationship of the individual with God and His Manifestation; of the individual toward his or her true self; of the individual and the family; of the individual toward others-indeed of the full range of relationships among individuals, groups, communities, and institutions within society, as well as between humanity and the physical environment. The growth and development of the Faith is a process of learning, individually and collectively, about the formation of these new relationships at ever higher degrees of complexity, as they will, in the fullness of time, give rise to a new pattern of social organization for humanity.

To the extent that we bring ourselves into alignment with Bahá'u'lláh's moral teachings - that is, the more we are able to cultivate the set of proper relationships within ourselves and with others - the more effective we become in the pursuit of our twofold purpose. Think of an electromagnet. When the proper conditions of the core, the wire, and the power source exist, electricity can flow creating a magnetic force that affects the world around it. If these conditions do not exist - a non-metallic core or a high resistance wire - the power cannot appear, and the capacity to affect the surroundings does not become manifest.

The potential for change offered by Bahá'u'lláh's teachings presents humanity with a profound moral challenge: the end of evil. The nature of suffering is a mysterious and inherent aspect of the material world. Human life in the material world is a journey of the soul, and suffering is a part of that journey without which it would not be possible to know joy or make spiritual progress (J. Hatcher). However, the nature of evil in the world is different; it arises from willful human action that does harm to others. Therefore, it can be eliminated. "Every good thing is of God, and every evil thing is from yourselves," Bahá'u'lláh explains (Gleanings 77:1). He further states: "Indeed the actions of man himself breed a 
profusion of satanic power.... A world in which naught can be perceived save strife, quarrels and corruption is bound to become the seat of the throne, the very metropolis, of Satan." Yet, "were men to abide by and observe the divine teachings, every trace of evil would be banished from the face of the earth" (Tablets 176-77).

\section{SPIRITUALITY AND MoRALITY}

The points raised above should not be misinterpreted. For a Bahá'í, there can be no reduction of religion to mere moral behavior. For a Bahá'í, the moral life is the Bahá'í life. This means that for a Bahá'í the starting point for attaining to the standard of true morality, the understanding of how life ought to be lived, how society ought to be organized, what we owe to one anotherall this begins with a particular conviction that is the essence of religion: the personal experience of the recognition of the Manifestation of God in His Day and certitude in His reality. This is the first of the twin duties Bahá'u'lláh ordains for every human being in the Kitáb-i-Aqdas. As a result, the rational soul becomes a new creation, reborn and animated by the spirit of faith. The second corresponding duty, derived from and motivated by this inner conviction that unites the individual with God, is "to observe every ordinance of Him Who is the Desire of the world" (Kitáb-i-Aqdas 『1). It is the inner spiritual conviction that gives rise to the motive force for moral action. These are the twin duties enjoined in the
Kitáb-i-Aqdas, and neither is acceptable without the other.

Thus, spirituality and morality are, from Bahá'u'lláh's perspective, inseparable. A spirituality without the fruits of moral action is illusion. Also, one cannot know true morality, much less live a truly moral life, without the association of the moral standard with something more than human preference. Morality is associated with that standard provided by the Manifestation of God, a standard that one recognizes and desires to uphold out of love of His Beauty.

"Think not that We have revealed unto you a mere code of laws," Bahá'u'lláh states in that Most Holy Book. "Nay, rather, We have unsealed the choice Wine with the fingers of might and power" (Kitáb-i-Aqdas 9 5). This choice wine is His Revelation. Through the Revelation, He explains who human beings are and what they are to do, individually and collectively, to live a good and meaningful life and contribute to the betterment of the world. "The first thing to do is to acquire a thirst for Spirituality," "Abdu'l-Bahá is reported to have said, "then Live the Life! Live the Life! Live the Life!" (Compilation v. 1 no. 425). To "live the life," a letter written on behalf of the Guardian explains, is "to have our lives so saturated with the Divine teachings and the Bahá'í Spirit that people cannot fail to see a joy, a power, a love, a purity, a radiance, an efficiency in our character and work that will distinguish us. ... Unless we can show this transformation in our lives, this new power, 
this mutual love and harmony, then the Bahá'í teachings are but a name to us" (Compilation v. 2 no. 1271).

A statement attributed to 'Abdu'lBahá captures the distinction between the moral life and spiritual life that is the standard of true morality. "Moral life consists in the government of one's self," $\mathrm{He}$ is reported to have said. "Immortality is government of a human soul by the Divine Will" (qtd. in Grundy 5). A standard of morality established by human beings is fallible. It is always subject to debate and contention. Morality derived from human invention too easily drifts to the extremes, governed by ideological orthodoxy or mere personal desire. On one extreme, as previously mentioned, ideology of various kinds displaces the human being as the highest value, and human beings may be sacrificed on the altar of these beliefs. On the other, human beings are always tempted to define moral standards according to their personal desires, rather than control desire in pursuit of moral good. The product of these extremes is the victory of the struggle for existence-morality never rises above rationalization. The divine standard is the moral objective toward which human understanding and action turn to achieve their highest expression. Naturally, human understanding and action are partial and fallible, but they can advance over time.

The inner and outer moral transformation which leads to meaningful and fulfilling human life and to the betterment of the world is, at its heart, a change in relationships. This includes the relationship of the individual with God, with Bahá'u'lláh and His Covenant, with the self, with other people, with nature and the material world; as well as the many permutations of relationships among groups, society, institutions, and civilizations. These relationships are recast in light of Bahá'u'lláh's teachings and it is the obligation of Bahá'ís to learn to translate these teachings into action. As they learn to be more effective in their expression of these teachings, then, in the fullness of time, the institutions of society take the form of a New World Order, society transforms to become a spiritual civilization, and individuals become a new human race. "A race of men incomparable in character, shall be raised up," Bahá'u'lláh has promised, "which . . . will cast the sleeve of holiness over all that hath been created from water and clay" (qtd. in Shoghi Effendi, Advent 31). Holiness is the attainment of spiritual and moral excellence; to live a Bahá'í life is to endeavor to bring spiritual and moral excellence to the entire creation.

For Bahá'ís, then, spirituality is the conscious knowledge and action of responsible agents aimed at bringing into being just and proper relationships that organize humanity's inner and outer life. It is not confined to correct private thoughts about knowledge or virtue or Bahá'í theological concepts. Bahá'u'lláh did not come to make us mere mystic knowers as an end in itself; He unlocked mystic knowledge and revealed truths never before known 
so we could translate these truths into reality and action to transform individuals and the social order. Spiritual quickening is not the end point of human aspiration, it is the beginning of a process that leads to the transformation of the physical and social world to make it the kingdom of God on earth. Being and doing are a coherent whole.

In Some Answered Questions, 'Abdu'l-Bahá discusses the relationship between faith and deeds. He explains that "the foundation of success and salvation is the recognition of God, and that good deeds, which are the fruit of faith, derive from this recognition." "When this recognition is not attained, man remains veiled from God and, as he is veiled, his good works fail to achieve their full and desired effect." Yet, this "does not mean that those who are veiled from God are all equal, whether they be doers of good or workers of iniquity. It means only that the foundation is the recognition of God and that good deeds derive from this knowledge. Nevertheless, it is certain that among those who are veiled from God there is a difference between the doer of good and the sinner and malefactor" (65.2-3). Thus, deeds ought to be good; actions ought to be moral. And when anchored in spiritual conviction, moral action becomes deeply rooted, properly directed, and more potent; it is light upon light.

Thus, for Bahá'ís, the association between recognition and obedience, between faith and deeds, between the inner and outer life, is clear. The conviction, or certitude, in the reality of the Manifestation of God must find its expression in the deeds that He ordains. It is unproductive to engage in any attempt to separate the two, or to consider the material and social teachings of Bahá'u'lláh as something apart from, or secondary in status to, the spiritual teachings of the Faith (Tabernacle 2.20). Rather, to speak of morality in relation to the Faith-to what human beings ought to do, to what we owe one another, and to how society should be organized - is to recognize its inseparability from spiritual reality. When Bahá'ís speak of social action, for example, it is never a reference to mere humanitarian deeds, but to the effort to adjust the arrangement of human affairs and work for the betterment of the world by translating Bahá'u'lláh's teachings into reality, leading ultimately to the attainment of spiritual civilization. To speak of the objectives of a particular Plan is not to become preoccupied with specific activities and procedures, but to carry forward the divine mandate for the spiritual illumination of the planet. All such thought and action directed to these ends is an expression of the inner spiritual conviction of faith in God and allegiance to Bahá'u' lláh that is translated into reflective, goal-directed, spiritually grounded action for the attainment of the Divine Purpose.

Contours of the Standard

of True Morality Found IN BAHÁ'U'LLÁH'S TEACHINGS

Bahá'u'lláh's Revelation is replete with guidance pertaining to the moral change necessary to reform humanity's inner and outer life. It includes not 
only a body of virtues or a description of what the new moral standard ought to be as set forth in His laws and exhortations, as well as what the outcome should be in terms of the wellbeing of and new relationships among individuals, communities and institutions born from their relationship with God and His Manifestation, but also a consideration of how these moral aims are to be realized.

Because human conscience is free, a solution cannot be imposed. But humanity must gradually be persuaded and educated, by word and deed, to discover that Bahá'u'lláh's prescription provides the remedy for humanity's grave ills. Bahá'ís have to learn to put this standard into practice in their own lives, families, communities, and relationships with others-in ever-widening social spaces. It is not possible here to even begin to capture the full contours of Bahá'u'lláh's standard of true morality. A summary of a few key concepts, which would be part of a framework for moral action derived from the Teachings, must suffice.

\section{THE INDEPENDENT INVESTIGATION OF REALITY}

Bahá'u'lláh upholds freedom of conscience of every soul in its effort to achieve its moral purpose. "The first teaching of Bahá'u'lláh is the duty incumbent upon all to investigate reality," 'Abdu'l-Bahá explains. "What does it mean to investigate reality? It means that man must forget all hearsay and examine truth himself, for he does not know whether statements he hears are in accordance with reality or not. Wherever he finds truth or reality, he must hold to it, forsaking, discarding all else; for outside of reality there is naught but superstition and imagination" (Promulgation 62). Too often, prejudice and superstition are used to manipulate and divide human beings in pursuit of self-interest; a myriad social ills flow from blindly accepting and rationalizing the self-interested narrative of one human tribe versus another. In a world where individuals, groups, and institutions increasingly obscure the truth in an effort to triumph in various contests for power to control the thoughts and actions of others - the continuing struggle for existence- this fundamental principle of Bahá'u'lláh becomes increasingly important in resisting the forces of a disintegrating order and in contributing to the construction of a new one in its stead.

\section{LOVE}

Bahá'u'lláh explains that, "The beginning of religion is love for God and for His Chosen Ones, and its end is to manifest that love to His servants" (Call 3.8). Love is the power that can transform human hearts. "Let your hearts be filled with the great love of God, let it be felt by all;" 'Abdu'l-Bahá states, "for every man is a servant of God, and all are entitled to a share of the Divine Bounty. Especially to those whose thoughts are material and retrograde show the utmost love and patience, thereby winning them into 
the unity of fellowship by the radiance of your kindness" (Paris Talks 27). He urged the believers to "strive with all their might until universal fellowship, close and warm, and unalloyed love, and spiritual relationships, will connect all the hearts in the world" (Selections 7:1). In its letter dated 22 July 2020 to the Bahá'ís of the United States, the House of Justice stressed the vital importance of love in creating the susceptibilities in human hearts for moral persuasion and change in the existing fragmented relationships among human beings.

\section{JUSTICE}

Justice, Bahá'u'lláh explains, "consisteth in rendering each his due" (Tabernacle 2.37). It is "the best beloved of all things" in God's sight (Tablets 36). It is a "powerful force," "the conqueror of the citadels of the hearts and souls of men, and the revealer of the secrets of the world of being, and the standard-bearer of love and bounty" (Epistle 32) and its purpose "is the appearance of unity among men" (Tablets 67). Bahá'u'lláh's conception of justice encompasses the highest aspirations of human thought over the centuries. Justice is a virtue, a spiritual attribute that is an integral part of human nature and that must be cultivated. It also pertains to principles, exhortations, and laws that, as they are universally adopted, will transform the relations among individuals, communities, and institutions. Further, justice is associated with those outcomes of the social order which are conducive to human flourishing, happiness, wellbeing, and the common good. Justice - for all without exceptional accommodations for "us" and "them"- provides the standard to guide thought and action in making the necessary arrangements for the reconstruction of the social order for the age of human maturity.

\section{WISE AND MODERATE SPEECH}

Bahá'u'lláh explains that, "Human utterance is an essence which aspireth to exert its influence and needeth moderation" (Tablets 143). In past ages, diversity of human thought was suppressed by obedience to authority, and later, when the expression of views was finally liberated, it often took the form of argumentation, extreme conflict, and contest for power that made it difficult for truth to prevail. In contrast, Bahá'u'lláh explains that, "It behoveth a prudent man of wisdom to speak with utmost leniency and forbearance so that the sweetness of his words may induce everyone to attain that which befitteth man's station." (Tablets 173). He outlined an approach to cooperative human utterance - consultation - which allows for a collective search for the truth of a matter to determine appropriate action according to circumstances. In this process of consultation, individuals offer opinions without passion or rancor, contention is forbidden, participants listen to the views of others and if they hear a better idea, they embrace it without stubbornly clinging to personal views. A spirit of cooperation and 
respect prevails and, after consensus is formed, a conclusion is supported by all and tested in action to determine if it is effective. Reflection on action and further consultation leads to learning and refinement of understanding and practice. While this mode of discourse may appear at first glance to be utopian or naïve, Bahá'ís have established it as effective practice in diverse cultural settings worldwide.

\section{EDUCATION AND SPIRITUAL EMPOWERMENT}

Bahá'ís recognize that every people, every person, has the right to be a protagonist in the process of working for the betterment of the world. Development is not something one group carries out for another. According to the Bahá'í teachings, it is essential, then, that human beings receive an education so that the potentialities latent in every soul find their full and effective expression, and so that the generation and accumulation of knowledge can support the advancement of civilization. This education should be material, social, moral, and spiritual. "The primary, the most urgent requirement is the promotion of education," "Abdu'l-Bahá explains. "It is inconceivable that any nation should achieve prosperity and success unless this paramount, this fundamental concern is carried forward" (Secret 109).

\section{TOLERANCE AND RIGHTEOUSNESS}

"The heaven of true understanding shineth resplendent with the light of two luminaries: tolerance and righteousness," Bahá'u'lláh states (Tablets 169-70). These are "two lights amidst the darkness of the world and two educators for the edification of mankind" (Tablets 36). Human beings are generally tolerant toward themselves and those like themselves, while being self-righteous toward others, easily finding fault with their perceived shortcomings, limitations, or beliefs. What is needed, if human relationships are to be well founded, is the reverse: tolerance toward others, while holding oneself or one's community to the obligation to do that which is right. Hypocrisy - the insistence upon moral standards or beliefs to which one's own behavior does not conform-is a formidable barrier to understanding and cooperation. "Be thou of the people of hell-fire," is Bahá'u'lláh's emphatic rebuke, "but be not a hypocrite" (Compilation no. 2050).

AVOIDING THE IMPOSITION OF VALUES

Human conscience is free-even to err- and must be persuaded and guided, not coerced. In becoming a Bahá'í, one freely accepts Bahá'u'lláh and commits to abide by His teachings. Bahá'ís do not abandon what Bahá'u'lláh has ordained or change it to accord with their own personal preferences, even if they struggle to live up to His standards. In the process of engaging others in the wider society in a search for truth, Bahá'ís seek out points of unity to work together for the common good. They do not judge others or impose on 
them their values. 'Abdu'l-Bahá explains that the Bahá'í Cause, "cometh neither for strife nor war, nor for acts of mischief or of shame; it is neither for quarrelling with other Faiths, nor for conflicts with the nations. . . . Its victory is to submit and yield, and to be selfless is its everlasting glory." The aim is empowerment and cooperation with others, not condemnation or contention. He concludes: "Let all your striving be for this, to become the source of life and immortality, and peace and comfort and joy, to every human soul, whether one known to you or a stranger, one opposed to you or on your side" (Selections 206:11).

\section{THE EMPIRICAL NATURE}

of Moral PRogress

For Bahá'ís, Bahá'u'lláh's moral teachings are derived from an accurate perception of human nature and of social reality. Learning to properly understand and apply these teachings leads to evident constructive change in human lives and in social progress. "When the fruit of the tree appears and becomes ripe, then we know that the tree is perfect; if the tree bore no fruit it would be merely a useless growth, serving no purpose," "Abdu'l-Bahá explains, "When a soul has in it the life of the spirit, then does it bring forth good fruit and become a Divine tree" (Paris Talks 98). The efficacy of Bahá'u'lláh's teachings is demonstrated in reality; learning through reflection on action creates improvement over time. The teachings address humanity where it is at the start of the dispensation, and are formulated to transform its inner and outer life to achieve its full potential in a global spiritual civilization by the end of the dispensation.

\section{The Covenant And AdMINISTRATION}

In addition to His teachings that inform a framework for moral action, Bahá'u'lláh has endowed His Revelation with distinct elements to assist the believers and ensure their success in achieving their high aims and ideals. The most distinctive of these elements - the example of 'Abdu'l-Bahá and the Covenant-are particularly worthy of note at this time of the centenary of the passing of 'Abdu'l-Bahá, when the House of Justice has called for "profound reflection" on His life, and on "the strength of the Covenant of which He was the Centre" (25 November 2020).

"It is evident that the axis of the oneness of the world of humanity is the power of the Covenant and nothing else," 'Abdu'l-Bahá states. In this way, He indicates that the Covenant has a vital function not only for Bahá'ís, but for all humanity. For as He further explained, "Had the Covenant not come to pass, had it not been revealed from the Supreme Pen and had not the Book of the Covenant ... illuminated the world, the forces of the Cause of God would have been utterly scattered. . ." (Tablets 49). Without the Covenant, the teachings of Bahá'u'lláh would not find their full expression, and the 
oneness of humanity could not be fully realized.

Learning to translate Bahá'u'lláh's teachings into action takes place within the context of the arrangements $\mathrm{He}$ has revealed for the Covenant and Administration. In past dispensations, the absence of an explicit Covenant resulted, over time, in the views of individuals gradually obscuring, diluting, or even altogether supplanting the true meaning of the Divine Teachings. The teachings would become mixed with personal opinions that invariably led to discord and division. Therefore, Bahá'u'lláh established His Covenant, and ordained an administrative order to ensure that His Revelation remains unadulterated and that the community remains united throughout the many stages of its evolution as the believers strive to apply His teachings ever more effectively.

The administrative system ordained by Bahá'u'lláh is, Shoghi Effendi explained, the nucleus and pattern of a new world order. Over the course of the dispensation, Bahá'ís are learning how to transform the relationships among individuals, communities, and institutions in the many complex configurations of a mature society. The outcome, in the fullness of time, is a new human race, a new world order and a spiritual civilization.

After His passing, Bahá'u'lláh instructed the friends to turn to 'Abdu'lBahá. 'Abdu'l-Bahá subsequently perpetuated Bahá'u'lláh's Covenant through His Will and Testament. "Unto the Most Holy Book every one must turn and all that is not expressly recorded therein must be referred to the Universal House of Justice," He states. "That which this body, whether unanimously or by a majority doth carry, that is verily the Truth and the Purpose of God Himself" (Will and Testament 39-40). "In the Bahá'í Faith there are two authoritative centers appointed to which the believers must turn," the House of Justice further explains, "one center is the Book with its Interpreter, and the other is the Universal House of Justice guided by God to decide on whatever is not explicitly revealed in the Book" (Messages:1963-1986 75.15).

With the passing of Shoghi Effendi the authoritative interpretation of the Text came to an end. Nevertheless, the evident meaning of the Book, including the body of existing authorized interpretation, is available to guide the action of the believers. As the House of Justice states in its Constitution: "The provenance, the authority, the duties, the sphere of action of the Universal House of Justice all derive from the revealed Word of Bahá'u'lláh which, together with the interpretations and expositions of the Centre of the Covenant and of the Guardian of the Cause - who, after 'Abdu'l-Bahá, is the sole authority in the interpretation of Bahá'í Scripture-constitute the binding terms of reference of the Universal House of Justice and are its bedrock foundation. The authority of these Texts is absolute and immutable until such time as Almighty God shall reveal His new Manifestation to Whom 
will belong all authority and power" (Constitution 4).

The Universal House of Justice is now, after the passing of Shoghi Effendi, the Head of the Faith to which all Bahá'ís turn. Its powers and duties, set forth in the Writings of Bahá'u'lláh, 'Abdu'l-Bahá, and Shoghi Effendi, are summarized in the Declaration of Trust that begins its Constitution. Among the functions of the House of Justice is the administration of the affairs of the Cause, the coordination of its activities, the promotion of its interests, the execution of its laws, and the defense of its institutions (World Order 148). Further, Shoghi Effendi explained, the House of Justice "is to lay more definitely the broad lines that must guide the future activities and administration of the Movement" (Administration 63). Acknowledging that certain practices of the community during his ministry were a temporary measure to be reconsidered by the House of Justice when it was finally established, the Guardian explained: "And when this Supreme Body will have been properly established, it will have to consider afresh the whole situation, and lay down the principle which shall direct, so long as it deems advisable, the affairs of the Cause" (Administration 41).

The House of Justice prescribes the proper action within the framework of the teachings according to the exigencies of the time: "Inasmuch as for each day there is a new problem and for every problem an expedient solution, such affairs should be referred to the Ministers of the House of Justice that they may act according to the needs and requirements of the time," Bahá'u'lláh states (Tablets 27). This includes directing the evolution of the administrative order and designing the successive stages of the unfoldment of the Divine Plan (Unfolding Destiny 216). While possessing the exclusive right to legislate on matters not explicitly revealed in the Most Holy Book, in the absence of the Guardian, the House of Justice carries forward their common object "to insure the continuity of that divinely-appointed authority which flows from the Source of our Faith, to safeguard the unity of its followers and to maintain the integrity and flexibility of its teachings" (Shoghi Effendi, World Order 148). Further, as 'Abdu'l-Bahá explains, it deliberates "upon all problems which have caused difference, questions that are obscure and matters that are not expressly recorded in the Book. Whatsoever they decide has the same effect as the Text itself" (Will and Testament 40). "By this body all the difficult problems are to be resolved" (Will and Testament 29).

Thus, the Covenant provides the means necessary to ensure that the believers receive the reliable and binding guidance essential to make certain that Bahá'u'lláh's teachings are safeguarded and properly applied in order to achieve His purpose over the course of the dispensation. Because Bahá'u'lláh established this Covenant, and because $\mathrm{He}$ guarantees the protection of the House of Justice, the believers are assured that the guidance they receive is in keeping with Bahá'u'lláh's 
intent. Yet, in no way is the Covenant an obstacle to freedom of thought and action. 'Abdu'l-Bahá states that "the moderate freedom which guarantees the welfare of the world of mankind and maintains and preserves the universal relationships, is found in its fullest power and extension in the teachings of Bahá'u'lláh" (Selections 227:27). Bahá'u'lláh does not ask that we follow Him blindly, but that we use the capacities God has bestowed on us-including the full power of the intellect - to understand and apply His teachings. Human minds differ and all ways of human knowing are limited, 'Abdu'l-Bahá explains in various passages, and therefore people naturally have diverse opinions on a wide range of subjects. It is obvious, then, that in relation to any decision reached by an institution, some people will agree and some will disagree; this is the source of political or religious conflict. In the Faith, however, these differences are reconciled. The Covenant safeguards the exchange of diverse views in the search for truth and the building of a new world, while preventing the contention, conflict, heresy, and division - even hatred and warfare- that eventually befell religion in previous dispensations. The Covenant fosters and preserves sound relationships among individuals, communities, and institutions, ensuring the rights and responsibilities of each of these protagonists engaged in a conscious learning process to apply Bahá'u'lláh's teachings for personal and social transformation in a worldwide network, from the grassroots to the international level.

With the Covenant at their heart, then, Bahá'u'lláh's teachings function like the laws and procedures of a system of traffic management. The intention and outcome of such laws is not restriction but freedom: they preserve the ability to move freely and efficiently; without them, safety and movement are impossible. In the Bahá'í Faith, individuals are free to express their views, including criticisms, through designated means. Other believers listen without becoming overawed by new or possibly erroneous ideas, sharing in turn their own views in the search for truth. Where collective action is required, consultation provides the means to reach decisions that are embraced by all and tested through experience and further reflection. On all subjects that have caused difference, questions that are obscure, or matters that are not addressed in the Book, the authoritative decision rests with the Universal House of Justice. The Covenant is the axis of the oneness of humanity because it preserves the unity and integrity of the Faith itself and protects it from being disrupted as individuals, communities, and institutions learn to apply the teachings and build the sound and transformative relationships which will make the unity of the human race a reality.

\section{The Example of ‘AbDU’L-BAhÁ}

The second distinctive element offered by Bahá'u'lláh to the Bahá'í community to assist it to achieve its high aims 
was His son, 'Abdu'l-Bahá, the Centre of the Covenant after the passing of Bahá'u'lláh. He is the embodiment of every Bahá'í ideal, the perfect exemplar to whom Bahá'ís turn to understand what it means to live a life in accordance with Bahá'u'lláh's teachings. It is common for Bahá'ís to see in the stories of 'Abdu'l-Bahá's life the practical expression of various spiritual qualities which they should appreciate and strive to emulate; indeed, such vignettes are a cornerstone of the moral education of young Bahá'ís. Perhaps it is also possible, looking at His example in a slightly different way, to try to draw insight into how 'Abdu'l-Bahá acted as a moral agent to transform the relationships among human beings in the effort to create a just world.

First among these insights is 'Abdu'l-Bahá's intellectual example in remolding the moral foundations of society. In one of His Tablets pertaining to 'Abdu'l-Bahá, Bahá'u'lláh states: "We pray God to illumine the world through Thy knowledge and wisdom" (qtd. in Shoghi Effendi, World Order 135). And so it was that 'Abdu'lBahá's Will and Testament perpetuated the Covenant and inaugurated the administrative order, thereby securing the axis of the oneness of humanity. His Tablets of the Divine Plan provided the charter for the expansion and consolidation of the Faith worldwide. In The Secret of Divine Civilization, $\mathrm{He}$ offered an understanding of the spiritual and moral foundations for the development of peoples and nations. And in the Tablet to the Hague, and in His various talks as $\mathrm{He}$ travelled in the West, He demonstrated how to elevate the discourse among peoples on a host of subjects to look at problems from a perspective that assists humanity to overcome differences and search together for effective solutions. An example is His discussion of world peace, raising the issue beyond a mere end to war to a consideration of a range of relationships that must be adjusted if a peaceful world is to result-including the equality of women and men, the elimination of prejudices of all kinds, the end of religious strife, the need for universal education, and so on.

These seminal works, along with countless other Tablets, not only provide a foundation for all areas of endeavor of the Bahá'í world today, but also a rich illustration of how Bahá'ís can direct their own intellectual energies to address the wider society about the needs of the age. This example is increasingly important in an age in which individuals obscure the truth and seek to foster conflict and contention in pursuit of power and personal gain. "The principal reason for the decline and fall of peoples is ignorance," 'Abdu'l-Bahá warns. "Today the mass of the people are uninformed even as to ordinary affairs, how much less do they grasp the core of the important problems and complex needs of the time." "It is therefore urgent that beneficial articles and books be written, clearly and definitely establishing what the present-day requirements of the people are, and what will conduce to the happiness and advancement of 
society," He adds. "The publication of high thoughts is the dynamic power in the arteries of life; it is the very soul of the world" (Secret 109).

Another example offered by 'Abdu'lBahá is His firm grasp of His identity. He was the servant of Bahá'u'lláh, and nothing could shake Him from the course set by adherence to this path. 'Abdu'l-Bahá's adamantine embrace of His identity made Him one with every human being and consecrated to His twofold purpose. He could not be swayed or tempted to compromise in the face of praise or blame. "I have set forth that which is conducive to human progress and shown you the humility of servitude," He said (Promulgation 460). And He called for us to follow in this path: "look at Me, follow Me, be as I am; take no thought for yourselves or your lives, whether ye eat or whether ye sleep, whether ye are comfortable, whether ye are well or ill, whether ye are with friends or foes, whether ye receive praise or blame" (qtd. in Balyuzi 73).

In the world today, differences of identity multiply in countless moral tribes that divide humanity into competing visions of truth and moral purpose. Each Bahá'í also hears the call of tribes, ethnicities, races, religions, nations, gender, political parties, ideologies, and so on. Shoghi Effendi explains that being a Bahá'í does not conflict with lesser loyalties, but calls for a wider loyalty, recognizing that "the advantage of the part is best to be reached by the advantage of the whole" (World Order 198). To be a Bahá'í does not mean one's life is a perfect expression of the Bahá'i teachings, but it is a commitment to struggle and strive to practice them every day. And in the effort to live a Bahá'í life, one cannot compromise the requirements of the teachings for the sake of personal desires or in the face of praise or blame.

Still another essential example demonstrated by 'Abdu'l-Bahá was the nature of His discourse-His engagement with others. In a world divided by countless competing factions of us and them, in which language is used to create a greater divide and enflame a contest for power, 'Abdu'l-Bahá sought to use a language that would elevate discourse above points of contention, foster a common investigation of reality, unite people in the search for truth and the solutions to problems, and forge a common identity based on the oneness of humanity. Moral discourse persuades and empowers; it does not mislead or coerce. In a talk, Bahá'u'lláh extolled the manner in which 'Abdu'l-Bahá sought to engage others:

Whatever a person says, hollow and product of vain imaginings and parrot-like repetition of somebody else's views though it be, one ought to let it pass. One should not engage in disputation leading to and ending with obstinate refusal and hostility, because the other person would consider himself worsted and defeated. . . . One ought to say: right, admitted, but look at the matter in this other 
way, and judge for yourself whether it is true or false; of course it should be said with courtesy, with kindliness, with consideration. . . . He will agree, because he comes to realize that the purpose has not been to engage in verbal battle and to gain mastery over him. He sees that the purpose has been to impart the word of truth.... His eyes and his ears are opened, his heart responds, his true nature unfolds. . (qtd. in Balyuzi 27).

The meaning of these reported words of Bahá'u'lláh is captured in countless statements in the Bahá'í Writings. "Do not argue with anyone, and be wary of disputation," Abdu'l-Bahá states. "Speak out the truth. If your hearer accepteth, the aim is achieved. If he is obdurate, you should leave him to himself, and place your trust in God." "The friends of God should weave bonds of fellowship with others and show absolute love and affection towards them," He also explains. "These links have a deep influence on people and they will listen." And He further advises:

Follow thou the way of thy Lord, and say not that which the ears cannot bear to hear, for such speech is like luscious food given to small children. However palatable, rare and rich the food may be, it cannot be assimilated by the digestive organs of a suckling child. Therefore unto every one who hath a right, let his settled measure be given.
"Not everything that a man knoweth can be disclosed, nor can everything that he can disclose be regarded as timely, nor can every timely utterance be considered as suited to the capacity of those who hear it." Such is the consummate wisdom to be observed in thy pursuits. Be not oblivious thereof, if thou wishest to be a man of action under all conditions. First diagnose the disease and identify the malady, then prescribe the remedy, for such is the perfect method of the skillful physician (Compilations 300-301).

An example of this type of engagement is 'Abdu'l-Bahá's discussion of the extremes of wealth and poverty. Despite some progress in assisting the poorest of the poor, this problem has in many ways only intensified since 'Abdu'l-Bahá addressed it. According to some reports, one percent of humanity has twice the wealth of some ninety percent of the rest of humanity. About 2,800 people-the world's billionaires - have the same wealth as some sixty percent of the planet (Oxfam). The same extremes apply to differences among countries - some have enormous wealth while others are trapped in poverty and debt. This economic outcome is not the result of chance occurrence, or the inevitable expression of free markets and entrepreneurial merit. It is the result of human choice about the structure of society and human relationships and the imposition of power. A business or economic plan that intentionally profits its initiators 
by exploiting employees, harming the wellbeing of society, or damaging the planet itself is inherently unjust. It does not have to be permitted. If we think and act differently, it is possible to attain a different result.

'Abdu'l-Bahá framed the conversation around the elimination of the extremes of wealth and poverty in a manner characterized by early Bahá'ís as a spiritual solution to the economic problem. Bahá'u'lláh makes it evident that human beings are not, in essence, economic beings. He is not, however, opposed to wealth. Spiritual progress, He indicates, is made possible by material means (Compilations no. 1099). When spiritual maturity is attained, then wealth is needed (Tablets 35). Wealth should be properly acquiredthrough productive work - and properly expended-for human well-being. As 'Abdu'l-Bahá states:

Wealth is praiseworthy in the highest degree, if it is acquired by an individual's own efforts and the grace of God, in commerce, agriculture, art and industry, and if it be expended for philanthropic purposes. ... Wealth is most commendable, provided the entire population is wealthy. If, however, a few have inordinate riches while the rest are impoverished, and no fruit or benefit accrues from that wealth, then it is only a liability to its possessor. (Secret 24-25)

A just economic system would meet the minimum requirements of every human being, so that they are able to achieve their twofold purpose, while not causing harm to the earth, thereby creating a relationship of harmony between humanity and the physical world. This does not require equal outcomes. 'Abdu'l-Bahá explains that "absolute equality" is "untenable, for complete equality in wealth, power, commerce, agriculture, and industry would result in chaos and disorder, disrupt livelihoods, provoke universal discontent, and undermine the orderly conduct of the affairs of the community. For unjustified equality is also fraught with peril." At the same time, "the greatest oppression and injustice are to be found" when "wealth, power, commerce, and industry are concentrated in the hands of a few individuals, while all others toil under the burden of endless hardships and difficulties, are bereft of advantages and benefits, and remain deprived of comfort and peace. (Some Answered Questions 78.4-5).

Without calling for a particular type of economic system, 'Abdu'l-Bahá discussed the spiritual and moral characteristics of an economic order that respects humanity's equality of condition. Every person, to achieve their true purpose, requires basics such as food, a place to live, health care, retirement. In one economic approach such needs can be met by means of just pay and profit-sharing, for example, or through taxes and supplementary government programs, in another. 'Abdu'l-Bahá explains that "insofar as the mutual rights of the factory owners and the workers are concerned, laws must be 
enacted that would enable the former to make reasonable profits and the latter to be provided with their present necessities and their future needs, so that if they become incapacitated, grow old, or die and leave behind small children, they or their children will not be overcome by dire poverty" (Some Answered Questions 78.8). Ultimately, He states, a satisfactory outcome is not the result of force (Selections 79:3), but of justice and moral persuasion (Promulgation 238-39). "It is therefore clearly established that the appropriation of excessive wealth by a few individuals, notwithstanding the needs of the masses, is unfair and unjust, and that, conversely, absolute equality would also disrupt the existence, welfare, comfort, peace, and orderly life of the human race. Such being the case, the best course is therefore to seek moderation" (Some Answered Questions 78.7).

This, of course, is but one example among many of how 'Abdu'l-Bahá lifted a heated debate above personal belief and self-interest to seek a moral basis for uniting people in the search for just solutions and attainment of the common good.

\section{Shoghi Effendi's Moral Treatise}

With these insights into the moral framework provided by Bahá'u'lláh's teachings, His Covenant, and the example of their translation into reality offered by the life of 'Abdu'l-Bahá, it is now possible to appreciate how Bahá'ís are working to transform their high ideals into practical action through an ever-wider engagement with peoples across the planet.

As the Bahá'ís of North America embarked upon the first Seven Year Plan, the first stage of the systematic execution of 'Abdu'l-Bahá's Plan for the spiritual transformation of the planet, Shoghi Effendi shared with them a seminal letter, published as a book entitled The Advent of Divine Justice. Upon reading the title, one might anticipate that the purpose of such a message was to lay out the basis and procedures of Bahá'í administration and the functioning of Spiritual Assemblies, which are in the fulness of time to become Houses of Justice. Yet, in fact, the book may be understood to be the Guardian's moral treatise on the Bahá'í teachings (Compilation 106). For it is not through the mere establishment of a system of jurisprudence or of a set of administrative procedures that the divine justice promised by Bahá'u'lláh will appear in the world. Creating the necessary relationships that will move humanity from its current stage of development to its ultimate destiny is a process of moral change.

Among the most fundamental themes of The Advent of Divine Justice is the promulgation of the teaching work. With but brief reflection, it should come as no surprise that moral transformation begins with teaching the Faith, so that every soul will know his or her true reality and purpose: what it means to be a human being and how to transform one's inner and outer life. For Bahá'u'lláh, teaching the Faith is not simply a process of the spiritual 
rebirth of individual souls; it is about restoring the collective life of humanity and reinvigorating its progress. "In this day," He stated, "We say: 'Come ye after Me, that We may make you to become the quickeners of mankind" (qtd. in Promised Day 174).

In this important work, Shoghi Effendi analyzes for the Bahá'ís of North America the problems afflicting American society, singling out for special consideration three evil tendencies: political corruption, moral laxity, and ingrained racial prejudice. He points out that, just as Iran was chosen to be the cradle of the Faith because of its shortcomings, America was chosen to be the cradle of Bahá'u'lláh's world order because of its moral failings, not because of any inherent superiority. "It is by such means as this," he wrote, "that Bahá'u'lláh can best demonstrate to a heedless generation His almighty power to raise up from the very midst of a people, immersed in a sea of materialism, a prey to one of the most virulent and long-standing forms of racial prejudice, and notorious for its political corruption, lawlessness and laxity in moral standards, men and women who, as time goes by, will increasingly exemplify those essential virtues of self-renunciation, of moral rectitude, of chastity, of indiscriminating fellowship, of holy discipline, and of spiritual insight that will fit them for the preponderating share they will have in calling into being that World Order and that World Civilization of which their country, no less than the entire human race, stands in desperate need" (Advent 19-20).
Shoghi Effendi observed that Bahá'ís, as part of their society, are also afflicted by these evil tendencies. At the time he addressed it, he noted that the Bahá'í community was too small to have a marked effect on society as a whole, and that the believers should begin by focusing on themselves; but he anticipated that, as their number and capacity grew, the time would come when they could begin to also contribute to addressing these same problems in the society around them. Ultimately, he envisioned, their contribution to the elimination of these moral failings of their society would be a decisive one, when they would be "called upon to eradicate in their turn such evil tendencies from the lives and the hearts of the entire body of their fellow-citizens" (Advent 21).

The Advent of Divine Justice emphasizes in unambiguous language that the work of the Faith is fundamentally a moral project, in which the range of relationships discussed above are profoundly out of order and must be restored and revitalized to enable humanity to achieve its purpose. The love of God must be rekindled, the understanding of one's true self and twofold purpose awakened. The right of every human being to develop and exercise their God-given powers must be respected and safeguarded, the relationships among diverse groups of peoples must be harmonized, and the institutional arrangements of society must be made free of oppression and corruption through adherence to the teachings and principles that reflect and establish the 
oneness of humanity. Different societies have different moral strengths, which represent a distinctive contribution to a shared global society, and each also has its moral ills, which must be overcome in the path of individual and social progress; the analysis that Shoghi Effendi carried out concerning the American Bahá'í community in The Advent of Divine Justice offers insight for the approach which every Bahá'í community faces in reading its particular social reality and enacting a constructive process of internal and social transformation.

In his argument, Shoghi Effendi describes for the American believers a "double crusade, first to regenerate the inward life of their own community, and next to assail the long-standing evils that have entrenched themselves in the life of their nation" (Advent 41). The double crusade restates for the community as a whole the twofold moral purpose of each human being, and it echoes Bahá'u'lláh's description of the purpose of the Manifestation to transform the inner and outer life of humanity. It involves the simultaneous effort of the American Bahá'í community to address the three spiritual prerequisites in its internal affairs, even as it sets out on its world embracing mission to diffuse the divine teachings.

In this double crusade, Shoghi Effendi directed the friends to apply the teachings to the best of their ability within all social spaces in which they participated. Rectitude of conduct, he explains, "must distinguish every phase of the life of the Bahá'i community" (Advent 2). It "must manifest itself, with ever-increasing potency, in every verdict which the elected representatives of the Bahá'í community, in whatever capacity they may find themselves, may be called upon to pronounce. It must be constantly reflected in the business dealings of all its members, in their domestic lives, in all manner of employment, and in any service they may, in the future, render their government or people" (Advent 26). "A chaste and holy life," he states, "must be made the controlling principle in the behavior and conduct of all Bahá'ís, both in their social relations with the members of their own community, and in their contact with the world at large." "It must be upheld, in all its integrity and implications, in every phase of the life of those who fill the ranks of that Faith, whether in their homes, their travels, their clubs, their societies, their entertainments, their schools, and their universities. It must be accorded special consideration in the conduct of the social activities of every Bahá'í summer school and any other occasions on which Bahá'í community life is organized and fostered" (Advent 29-30). Finally, freedom from racial prejudice "should be consistently demonstrated in every phase of their activity and life, whether in the Bahá'í community or outside it, in public or in private, formally as well as informally, individually as well as in their official capacity as organized groups, committees and Assemblies. It should be deliberately cultivated through the various and everyday opportunities, no 
matter how insignificant, that present themselves, whether in their homes, their business offices, their schools and colleges, their social parties and recreation grounds, their Bahá'í meetings, conferences, conventions, summer schools and Assemblies" (Advent 36).

Since that time, Bahá'í communities have multiplied, expanding their numbers and their reach, including a much greater involvement in the life of society. This presents an even greater opportunity for the application of Bahá'u'lláh's teachings in larger and more diverse social settings. The Universal House of Justice has further expanded upon Shoghi Effendi's guidance, describing the necessary transformation of relationships within the myriad social spaces in which Bahá'ís participate up to the current day. Among its statements is this one written on its behalf to a Bahá'í in the United States in relation to race unity:

the Guardian is calling for the friends to address the question of race unity as a part of life in all of the social spaces in which they are engaged, and, similarly, the House of Justice is now saying that freedom from racial prejudice must be the watchword of Bahá'ís in the social spaces in which they are engaged for the activities of the Plan. In such intimate settings, people of diverse racial backgrounds encounter the Word of God, and in their efforts to translate the Teachings into practical action, are able to generate bonds of love, affection, and unity, and to learn what it means to establish a true interracial fellowship that is powerful enough to overcome the forces of racism that afflict them and their society. Currently, among the Bahá'ís of the United States, race unity is a dimension of the work of community building in scores of clusters, of social action in hundreds of efforts of various levels of complexity, and of involvement in the discourses of society by thousands of believers in various settings. The House of Justice is confident that these endeavors will become more systematic, more widespread, and more effective as the learning process already set in motion by your National Spiritual Assembly is persistently pursued by the believers in greater numbers. (6 August 2018)

As the Divine Plan continues to unfold, the scope of the social spaces in which Bahá'ís are engaged will continue to expand and multiply, offering greater possibilities for transforming the human relationships through the insights derived from Bahá'u'lláh's teachings, until, in the fullness of time, Bahá'ís will witness the achievement of their high aspirations for justice, unity, and peace among all peoples and nations.

\section{The Bahá'í COMMUNITY'S Current EfForts}

The current social order is the reflection of the world's moral choices. The 
society we are trying to create in response to Bahá'u'lláh's wishes and in light of His teachings will be a moral achievement - it will be created by our thoughts, our discourse, our actions, and the sum of our relationships. By moral, again, in a Bahá'í context, is meant the kind of action grounded in spiritual conviction and obedience in response to divine love expressed in a twofold moral purpose. This effort is apparent in the current activities of Bahá'í communities worldwide in the context of the Divine Plan.

Every Bahá'í is striving to learn how to live a meaningful, good, coherent, and flourishing Bahá'í life, to create a work of moral artistry that is the story - in all of its many stages and chapters - of a life well-lived in accordance with Bahá'u'lláh's teachings. This Bahá'í life is propelled by the conviction of recognition of Bahá'u'lláh as the Manifestation of God for this age, leading to reflective action to create the proper relationships He has ordained.

Imagine, then, the process of waking up in the morning and beginning each day with the basic spiritual disciplines of prayer, meditation, reading the Writings, and bringing oneself to account, which strengthen the relationship of the individual with God, with Bahá'u'lláh and His Covenant, and with the self. Leaving the privacy of this chamber, one then goes into the world, to strengthen bonds with others-members of the family and of the community, in the neighborhood, at work, and in all the social spaces in which one participates - and thus to "cast the sleeve of holiness over all that hath been created from water and clay."

The efforts of individuals along this path come together in the collective endeavor of the community, and in particular its efforts to strive to implement the activities of the current stage of the Divine Plan. The Plan describes for the community what must be done according to the current needs of humanity and the latest stage of organic development of the Faith. Individuals, communities, and institutions in every part of the world then read their own social reality and determine what they will do. The recent series of Plans has vastly expanded the capacity of the Bahá'í world. Whereas before, Bahá'í communities were generally smallthe largest, with few exceptions, counting hundreds of members - currently, in the most advanced clusters the activities of the community now engage thousands, and a few even tens of thousands. All inhabitants of these clusters are welcome to participate in the activities of Bahá'í communities, whether they ultimately accept the Faith or not.

The spirit of this engagement is captured in one statement of Bahá'u'lláh about teaching the Faith: "The children of men are all brothers, and the prerequisites of brotherhood are manifold," He states. "Among them is that one should wish for one's brother that which one wisheth for oneself. Therefore, it behoveth him who is the recipient of an inward or outward gift or who partaketh of the bread of heaven to inform and invite his friends with 
the utmost love and kindness. If they respond favorably, his object is attained; otherwise he should leave them to themselves without contending with them or uttering a word that would cause the least sadness" (Tabernacle 2.39). Even if a person does not embrace the Faith, he or she is still your brother or sister, still part of the family, and all must learn to work together for the wellbeing of all.

Quantitative change in a cluster is matched by qualitative change in relationships, as reflected in countless reports worldwide. We can currently witness, to an increasing degree, entire villages united as one, where love and trust grow to the point that problems among families largely disappear and Local Spiritual Assemblies assume a respected position of moral leadership. In more and more clusters, young women are given unprecedented opportunities for participation and education, and the influence of oppressive social systems is dissipated. The behavior of young people is transformed, they take their studies more seriously and lead the way in social action. Principals, chiefs, and other leaders of thought acknowledge the noteworthy change in relationships and the betterment of the community. Progress, from place to place, is uneven, but what has been learned flows to all parts of the Bahá'i world, connecting the grassroots, regions, nations, continents, and the international level. Systematic efforts for community building are coherent with, and encompass locally, systematic efforts for social and economic development and involvement in the discourses of society. Every advance in this process is driven by learning how to translate what Bahá'u'lláh wrote into reality and action; thus, in all places, a nucleus of capable individuals who can read their reality, study the relevant teachings, implement a plan of action, raise up more and more individuals with the capacity to participate in the process, and reflect upon and revise action as needed-facilitate transformation and progress.

In this common enterprise, gradually, the relationships among individuals, communities and institutions take on new form. In the system created by Bahá'u'lláh, these three protagonists are inseparably associated and their efforts complementary. In the wider society, the various forms of relationships among these three are too often characterized by contention and the contest for power. In the efforts initiated by the Bahá'í community to which all are invited to participate, each of the three sees its responsibility to support and empower the other two, even to the extent of sacrifice. The divisions of "us" and "them" give way to the expression of the oneness of humanity in diverse social settings. 'Abdu'l-Bahá observed: "According to the teachings of Bahá'u'lláh the family, being a human unit, must be educated according to the rules of sanctity. All the virtues must be taught the family. The integrity of the family bond must be constantly considered, and the rights of the individual members must not be transgressed. The rights of the son, the 
father, the mother - none of them must be transgressed" (Promulgation 168). Just as a family advances when the pattern of rights and responsibilities is properly ordered and upheld, the same is true for the social order in general. Bahá'ís are now learning to apply the teachings within ever larger and more numerous social spaces.

The remedy to the division of humanity into contending moral tribes is moral persuasion, through distinctive words and deeds. If Bahá'ís succumb to merely parroting the discourse or mimicking the actions of contending factions in the contemporary spheres of knowledge, morals, politics, economics, and others, their efforts will be swept aside by the forces of disintegration, and they cannot hope to contribute to the change necessary for progress and human flourishing. The alternative is love and a discourse that unites and persuades, reshaping human association.

In environmental biology there is a concept called ecological succession that describes the emergence of a mature forest or its recovery after a devastating fire. The ecosystem is restored in distinct stages of relationships among soil, plants, and wildlife. So, for example, upon bare rock, microorganisms help soil form and rudimentary plant life takes root. As initial plants grow and die, organic matter is added. In this renewed substrate, grasses and then more complex and larger plants, and eventually shrubs and small trees can appear. More sophisticated plants support more advanced collections of insect and animal life. Each more complex stage of the ecosystem serves as a foundation for another, even more complex stage to appear until the mature forest emerges at a state of equilibrium.

The evolution of the relationships among individuals, communities, and institutions in the Faith can be understood as following this same pattern. The Báb, for example, raised up a community and organized it in such a way that its primary purpose would be the recognition of Bahá'u'lláh. During the ministry of Bahá'u'lláh, the Bahá'í community was increasingly organized in such a manner as to make it distinct from the Bábí community and ultimately prepare it to turn to 'Abdu'l-Bahá after Bahá'u'lláh's passing. The worldwide community was then organized around the person of 'Abdu'l-Bahá, consolidating its understanding of the Covenant, and extending its process of expansion and consolidation along the path $\mathrm{He}$ set out. During the time of Shoghi Effendi, the community evolved once more, and added new features, from the beginning of the Formative Age and the inauguration of the administrative order, to the 1950s with the start of its international institutional arrangements. The same process of successive stages in the evolution of the ecosystem of relationships within the Faith continues under the direction of the House of Justice. The past twenty-five years forged a pattern of arrangements that accelerated a global process of learning to advance the process of entry by troops; 
the decades ahead must further shape the relationships once more for an even more profound capacity to give expression to Bahá'u'lláh's teachings.

The work in community building, social action, and involvement in the discourses of society represents a continuing intellectual challenge to the Bahá'í world to which all of the friends have an opportunity to contribute, following in the footsteps of 'Abdu'lBahá. It consists in the generation and application of knowledge. Clusters have to reach new frontiers; material and social progress has to be advanced in villages and neighborhoods among all peoples by establishing projects and organizations dedicated to social and economic development; and insights from Bahá'u' lláh's teachings have to be introduced by individuals and institutions into the discourses of all the social spaces in which they participate. "O people of Baha!" Bahá'u'lláh exhorts, "The source of crafts, sciences and arts is the power of reflection. Make ye every effort that out of this ideal mine there may gleam forth such pearls of wisdom and utterance as will promote the well-being and harmony of all the kindreds of the earth" (Tablets 72).

Through the increased capacity cultivated by learning and the development of human resources, progress in the Bahá'í world accelerates exponentially. During the Ten Year Crusadecoming, as it did, at the climax of the learning process cultivated by Shoghi Effendi-more was accomplished in ten years than in the previous hundred. In the recent series of Plans, more was accomplished in the last five years than in the previous two decades. The pressing needs of humanity cry out for an even greater acceleration in the spiritual enterprise in which the Bahá'ís are engaged in the decades that lie ahead.

\section{Conclusion}

All peoples and nations are protagonists of the process of building the social world. All contribute to an ever-advancing civilization. This contribution-be it constructive or destructive - depends upon their understanding, their values, and their actions. The teachings of Bahá'u'lláh have been revealed to foster a constructive change in the inner and outer life of humanity. But a remedy must be applied. The purpose of the Bahá'í community is to understand and apply Bahá'u'lláh's teachings, and to do so in a manner that demonstrates their efficacy and persuades others through word and deed to also adopt this remedy to transform the relationships among human beings, leading to the creation of a just, unified, prosperous, and peaceful world. To do this, Bahá'ís, in keeping with their twofold moral purpose, are engaged in a process of learning how to apply Bahá'u'lláh's teachings in their own personal lives and in the ever wider circle of social spaces in which they participate, collaborating with all those in the wider society who are interested in the common enterprise of the betterment of the world.

There are no shortcuts, no formulas to achieve this end. It is not about 
imposing values on people. It is not about attempting to acquire power to compel the conscience or to force human beings to adopt particular policies or practices. It is about learning to translate the teachings into action and to assist others to do the same. It is about cultivating just patterns of association among individuals, communities, and institutions. It is about love-love that eliminates divisions of "us and them" to create the oneness of humanity and to bind people together in the search for truth and the resolution of humanity's ills. It is for Bahá'ís to serve as a leaven - a pervading influence-by striving, little by little and day by day, to do what is right and by engaging with all peoples who seek to transcend differences and work together for the common good. It is to strive to be the protagonists of a change in the relationships among human beings, the co-creators of a new spiritual and moral order in the world of humanity. As 'Abdu'l-Bahá explained in one of His talks:

You belong to the world of purity, and are not content to live the life of the animal, spending your days eating, drinking, and sleeping. . . . Your thoughts and ambitions are set to acquire human perfection. You live to do good and to bring happiness to others....

The Heavenly Father gave the priceless gift of intelligence to man so that he might become a spiritual light, piercing the darkness of materiality, and bringing goodness and truth into the world. If ye will follow earnestly the teachings of Bahá'u'lláh, ye shall indeed become the light of the world, the soul for the body of the world, the comfort and help for humanity, and the source of salvation for the whole universe. (Paris Talks 36:10)

\section{Works Cited}

'Abdu'l-Bahá. Paris Talks: Addresses Given by 'Abdu'l-Bahá in Paris in 1911-1912. Bahá'i Reference Library. bahai.org/ library/authoritative-texts/abdul-baha/paris-talks/

___. Selections from the Writings of 'Abdu'l-Bahá. Comp. Research Dept. of the Universal House of Justice. Bahá'i Reference Library. bahai.org/ library/authoritative-texts/ abdul-baha/selections-writings-abdul-baha/.

. Some Answered Questions. Bahá'í World Centre, 2014.

Tablets of the Divine Plan. US Bahá'í Publishing Trust, 1993.

. The Promulgation of Universal Peace: Talks Delivered by 'Abdu'l-Bahá during His Visit to the United States and Canada in 1912. Comp. Howard MacNutt. 2d ed. US Bahá'í Publishing Trust, 1982.

___ The Secret of Divine Civilization. US Bahá'í Publishing Trust, 1983. 
_- The Will and Testament of 'Abdu'l-Bahá. US Bahá'i Publishing Trust, 2013.

Bahá'u'lláh. Gleanings from the Writings of Bahá u'lláh. Trans. Shoghi Effendi. Bahá'i Reference Library. bahai.org/library/authoritative-texts/bahaullah/gleanings-writings-bahaullah/.

___ Epistle to the Son of the Wolf. US Bahá'í Publishing Trust, 1988.

—_. The Kitáb-i-Aqdas. Bahá'í World Centre, 1992.

—__ The Kitáb-i-Íqán. Trans. Shoghi Effendi. US Bahá’í Publishing Trust, 1974.

___ The Call of the Divine Beloved. Bahá'í World Centre, 2018.

__ . Tablets of Bahá'u'lláh Revealed after the Kitáb-i-Aqdas. US Bahá'í Publishing Trust, 1994.

__ Tabernacle of Unity. Bahá'í World Centre, 2006.

Balyuzi, Hasan. 'Abdu'l-Bahá: The Centre of the Covenant. George Ronald, 1972.

Greene, Joshua. Moral Tribes: Emotion, Reason, and the Gap Between Us and Them. Penguin Books, 2013.

Grundy, Julia Margaret Kunkle. Ten Days in the Light of 'Akka. US Bahá'í Publishing Trust, 1979.

Haidt, Jonathan. The Righteous Mind: Why Good People are Divided by Politics and Religion. Pantheon, 2012.

Hare, John E. God and Morality: A Philosophical History. Blackwell Publishing, 2007.

Hatcher, John. The Purpose of Physical Reality. US Bahá'í Publishing Trust, 2005.

Hatcher, William. Love, Power, and Justice: The Dynamics of Authentic Morality. US Bahá'í Publishing Trust, 1998.

Heil, John. The Philosophy of Mind. Routledge, 2013.

Karlberg, Michael. Beyond the Culture of Contest. George Ronald, 2004.

Lample, Paul. "In Pursuit of Harmony between Science and Religion." Journal of Bahá'i Studies, v. 26, no. 4, pp. 23-58. doi:10.31581/jbs-26.4.4(2016)

Oxfam International. philanthropynewsdigest.org/news/world-s-richest-1-percent-own-twice-as-much-as-bottom-90-percent

Redman, Earl. Shoghi Effendi: Through the Pilgrim's Eye, Volume 1: Building the Administrative Order, 1922-1952. George Ronald, 2015.

Ripley, Amanda. High Conflict: Why We Get Trapped and How We Get Out. Simon and Schuster, 2021.

Scanlon, T. M. What We Owe to Each Other. Belknap Press of Harvard UP, 1998.

Shoghi Effendi, Bahá 'í Administration. US Bahá'í Publishing Trust, 1998. - The Advent of Divine Justice. US Bahá'í Publishing Trust, 1984. 
___ The Promised Day is Come. US Bahá'í Publishing Trust, 1998.

__ . The World Order of Bahá 'u'lláh. US Bahá'í Publishing Trust, 1974.

___ Unfolding Destiny. UK Bahá'í Publishing Trust, 1981.

Taherzadeh, Adib. The Covenant of Baháu'lláh. UK Bahá'í Publishing Trust, 1992.

The Compilation of Compilations. Vol. 1 \& 2. Bahá’í Publications Australia, 1991.

The Universal House of Justice. Constitution of the Universal House of Justice. Bahá'í World Centre, 1972.

___ Messages of the Universal House of Justice: 1963-1986. US Bahá'í Publishing Trust, 1996.

—__ Messages of the Universal House of Justice: 1986-2001. US Bahá'í Publishing Trust, 2010.

___ Letter dated 22 October 1996 to an individual believer written on behalf of the Universal House of Justice with two memoranda from the Research Department.

___ _ Letter dated 6 August 2018 to an individual believer written on behalf of the Universal House of Justice.

__ _ Letter dated 22 July 2020 to the Bahá'ís of the United States.

___ Letter dated 25 November 2020 to the Bahá'ís of the World. 